\title{
Public Credit Programmes and Firm Performance in Brazil
}

\author{
Alessandro Maffioli $^{1} \quad$ | Joao A. de Negri ${ }^{2} \quad$ | Cesar M. Rodriguez ${ }^{3}$ | \\ Gonzalo Vazquez-Bare ${ }^{4}$
}

${ }^{1}$ Inter-American Development Bank

${ }^{2}$ Instituto de Pesquisa Econômica Aplicada

${ }^{3}$ Portland State University

${ }^{4}$ University of Michigan

\section{Correspondence}

Cesar M. Rodriguez, Department of

Economics, Portland State University, 1721

SW Broadway, Cramer Hall, Suite 241M,

Portland OR 97201

Email: cesar.rodriguez@pdx.edu

\begin{abstract}
Credit rationing is a common phenomenon faced by firms, one that has negative implications for long-term investments. In Brazil, public credit plays a key role in supporting firms: state-owned banks account for almost half of the outstanding credit. Public credit programmes aim at reducing credit restrictions, increasing competitiveness and job creation for small and medium enterprises. This article analyzes the effectiveness of the credit lines managed by two main public institutions in Brazil. Results show that access to public credit lines has a significant positive impact on firms' employment growth and exports, while no effect was found on wage differential. The impact on exports is driven by the increase in volumes among exporting firms rather than the probability of becoming an exporter.

\section{K E Y W O R D S}

Brazil, difference-in-differences, firm performance, panel data, public credit
\end{abstract}

\section{1 | INTRODUCTION}

Firms' access to credit is crucial, due to its potential to spur market development and entrepreneurial innovation (Schumpeter, 1961). Asymmetric information and transaction costs are usually the main

\footnotetext{
We are grateful to Patrick Franco Alves and Eduardo Ribeiro for useful discussions and comments on this project. We would also like to thank two anonymous referees for their suggestions and comments. The opinions expressed in this publication are those of the authors and do not necessarily reflect the views of the Inter-American Development Bank. The usual disclaimer applies. Senior authorship is not assigned.
} 
drivers of this credit rationing. Given the difficulty of obtaining information about a client's ability and willingness to repay a loan, financial entities cannot adequately calculate the risks of lending to said client and abstain from participating in the market, to charge interest rates that bear no relation to the client's solvency level, or to demand substantial collateral, which represents a constraint for the client. Brazilian firms are no exception to this problem. In fact, the lack of publicly available information about small and medium enterprises (SMEs) is one of the main reasons small businesses face insufficient access to credit (Bass \& Schrooten, 2006). As such, large firms often have easier access to financing than SMEs. The additional costs associated with the collection of relevant information of SMEs lead to high interest rates and potential differences in loan characteristics. In Brazil, two key institutions - the Banco Nacional do Desenvolvimento (BNDES) and the Financiadora de Estudos e Projectos (FINEP, Brazil's innovation finance agency) - developed specific public credit lines to channel credit to SMEs.

Discussions of the role of the public sector in the banking system are not new. Gerschenkron (1962) was one of the first to argue that, without public participation, the lack of trust among creditors and debtors would inhibit credit markets and thus long-term projects. Amsden (2001) and Armendáriz de Aghion (1999) contend that private banks underinvest in the expertise required to assess and promote new industries in the long run. More recently, Mazzucato and Penna (2016) posit that the problem is not only that markets could be working incorrectly, but that in some cases markets do not even exist. They further claim that mission-oriented projects aim to create new technological landscapes and solutions to fulfil the governmental mission.

According to Bruck (1998) and Levy-Yeyati, Micco, and Panizza (2004) in this industrial political view, state-owned development banks specialize in providing long-term capital and lending to firms that could not otherwise undertake projects. Public credit programmes carried out by state-owned development banks have been the main avenue of credit to finance firms not only in Latin America, but in developed and developing countries (Aronovich \& Fernandes, 2006; Rodrik, 2004). Examples include Brazil's BNDES, Germany's KfW, the Korean Development Bank, the Japan Development Bank, the Canadian Development Bank (now the Business Development Bank of Canada) and the China Development Bank. ${ }^{1}$

In Brazil, public credit plays an important role in supporting the productive sector. The BNDES was founded in 1952 as an institutional innovation in the Brazilian banking system filling an important gap: the provision of long-term loans for investment in manufacturing and infrastructure projects. In the 1980s, the focus of the Brazilian government was on the development of financial instruments for new ventures and SMEs (while also helping a number of companies facing difficulties due to the Brazilian debt crisis); in the 1990s, the focus shifted from specific programmes to finance innovation and high-tech firms. In the last decade, the Brazilian government enlarged its operational scope to include mission-oriented innovation. One of its defined missions has been to address the challenge of increasing expenditures in research and development (R\&D). As Mazzucato and Penna (2015) describe, BNDES and FINEP are the main public agencies in Brazil through which funds are channelled. Data show that the presence of these public agencies in the Brazilian banking sector is high.

\footnotetext{
${ }^{1}$ Since the mid-1950s, Germany's KfW has channelled funds for the promotion of long-term growth and infrastructure, providing finance for SMEs. In the 1960s, the Japan Development Bank began promoting the development of heavy industry and infrastructure, shifting their focus to financing technological development and innovation. The Canadian Development Bank seeks to promote innovation by providing capital assistance to firms with a special emphasis on SMEs. The Korean Development Bank, which was founded to supply capital and assist local industries after the Korean War, also targets the development of new sectors and technologies, such as electronics and the automotive industry. Finally, the China Development Bank, founded in 1994, focuses on regional economic development and industrial catching-up, supporting and nurturing new ventures.
} 
The largest state-owned development bank - the BNDES - accounted for $11 \%$ of all outstanding credit in 2006. Considering that the state also owns two of the three largest commercial banks in Brazil, the total percentage of outstanding credit accounted for by state-owned banks comes to around $44 \%$. Although the importance of the public sector in the Brazilian financial system has been broadly debated, little has been said about the effectiveness of these policy instruments in improving the conditions of final beneficiaries of these resources. The closest reference to our study is Lazzarini, Musacchio, Bandeira-de-Mello, and Marcon (2015), in which the authors analyze the effect of loans and equity instruments of BNDES on 286 Brazilian firms using data from the Sao Paulo Stock Exchange. ${ }^{2}$ However, their focus is on the impact on profitability and investment: they find that BNDES's loans and equity allocation do not have a consistent effect on profitability, market valuation or investment decisions. These results should be taken with caution, since the authors focus on a sample of firms traded on the stock exchange, which by their nature tend to be larger and less financially constrained than the overall population of firms receiving BNDES loans.

Our article contributes to this discussion by shedding light on the effectiveness of public credit programmes in promoting the performance of the Brazilian productive sector. In particular, we focus on the impact of the credit lines managed by BNDES and FINEP in fostering firms' employment, labour exports and wage differential. For this analysis we exploit a unique micro-level panel data set compiled by the Instituto de Pesquisa Econômica Aplicada (IPEA), which includes information on both firm-level performances and access to public credit lines for more than 231,000 firms. Our estimation strategy is based on a difference-in-differences methodology with quasi-experimental methods to control for selection bias when estimating the impact of the public credit lines.

Our results consistently show that access to public credit lines has a significant and robust positive impact on employment growth and exports, even as we do not find evidence of a significant effect on our measure of wage differential. Interestingly, our findings suggest that the impact on exports is driven by the increase in export volumes among exporting firms, while no significant effect on the probability of becoming an exporter is detected. Contrary to Lazzarini et al. (2015), our study finds a positive effect of the public credit policy effect of BNDES's loans. However, as previously mentioned, caution needs to be taken when comparing both studies since Lazzarini et al. (2015) analyze different outcomes and, most importantly, have a smaller sample size with larger firms. Interestingly enough, they also find that BNDES loans are not systematically channelled to underperforming firms, which could be consistent with our findings.

This article contributes to the literature by providing further evidence of the effectiveness of public credit programmes for Brazilian firms. In doing so, we further discuss our scope and findings alongside the most recent literature. Our analysis provides relevant answers for the policy-making in Brazil of public credit programmes, when the focus is on improving firm performance.

The article is structured as follows: section one provides a brief review on the justification of public credit programmes aimed at fostering firm performances and on the evidence of these programmes' effectiveness. Section two discusses in greater detail the main characteristics of public credit programmes in Brazil, with particular emphasis on the credit lines managed by BNDES and FINEP. Section three describes the data used in our analysis, including a review of the main basic statistics of interest. Section four discusses our identification strategy, focusing on the approach we adopted

\footnotetext{
${ }^{2}$ Other related studies include Pereira (2007) and Torres Filho and Pimentel Puga (2006). However, these authors mainly analyze the effect of BNDES loans on beneficiary firms, without a counterfactual analysis. Ottaviano and Lage de Souza (2008) measure the impact of BNDES funds use on the value added per worker using the annual industrial survey (Pesquisa Industrial Annual (PIA) from the Instituto Brasileiro de Geografia e Estatística (IBGE)). Their results - based on 9,000 firms - suggest that firms that contracted loans with BNDES experienced higher labour productivity only after two or three years, compared to firms that never contracted loans with the bank over a 10-year period. But the positive result appears only for firms that contracted large loans.
} 
to control for selection biases. Section five presents the results of our estimations, while section six concludes and provides some policy recommendations.

\section{DISCUSSION ON POTENTIAL IMPACTS OF CREDIT PROGRAMMES}

That informational asymmetries generate credit constraints appears to be a consensus in the literature, at least since Stiglitz and Weiss (1981) who state that credit rationing tends to appear in the form of higher interest rates (with a potential adverse selection problem), smaller loan sizes (to prevent greater risk) and larger collaterals. In turn, the fact that financial constraints may hinder firm performance has also been well studied. For instance, poor access to financial markets may negatively affect firm growth, especially among small firms (Beck, Demirgüç-Kunt, \& Maksimovic, 2005). Rendón (2000) shows that capital market imperfections may restrict the creation of permanent jobs, and notes the importance of removing financial constraints to promote job creation, particularly in economies with a high proportion of small firms. Moreover, the lack of access to credit may prevent firms from exporting, since this practice involves entry costs associated with acquiring information about foreign markets, customizing products to fit local tastes and setting up distribution networks (Minetti \& Zhu, 2011). Bellone, Musso, Nesta, and Schiavo (2010) argue that, in this context, public intervention can help efficient, but financially constrained, firms to overcome these fixed entry costs and expand their activities abroad.

Thus, in the presence of credit rationing, public financing may be an effective alternative to boost firm performance. ${ }^{3}$ The discussion of the role of the public sector in the banking system goes back at least to Gerschenkron (1962), who argues that without public participation, the lack of trust among creditors and debtors inhibits credit markets and thus long-term projects. Using a formal model, Armendáriz de Aghion (1999) argues that private banks underinvest in the expertise required to assess and promote new industries in the long run. Amsden (1989) argues that it is not only a matter of longrun capital availability, but that public credit financing also serves as a mechanism by which to screen good private projects and to enhance the execution of investments. More recently, Mazzucato and Penna (2016) suggest that the problem is not only that markets could be working incorrectly, but that in some cases markets do not exist at all. They further claim that mission-oriented projects are concerned with creating new technological landscapes and providing solutions to fulfil the governmental mission. Finally, according to Bruck (1998) and Levy-Yeyati et al. (2004), within this industrial political view, public credit programmes finance long-term capital and lending to firms that could not undertake projects due to the non-existence of long-term funding.

In fact, several empirical studies show that public credit is successful in relaxing financial constraints. For instance, Aivazian and Santor (2008) find that the World Bank's Small and Medium Industries programme in Sri Lanka led to a relaxation of credit constraints and higher levels of investment for firms that received the subsidies. This effect is, however, rather limited, despite the relatively large amount of resources committed to this purpose. They also find that the public guarantee substantially lowered the SMEs' borrowing cost. Banerjee and Duflo (2014) exploit the exogenous variation generated by a policy change in India to test whether firms are credit constrained based on their reaction to changes in directed lending programmes. According to the authors, while both constrained

\footnotetext{
${ }^{3}$ The rationale behind these public credit programmes is that only credit constrained firms will have access to those loans. Presumably, if a firm is not credit constrained, this additional liquidity could be used to substitute other sources of credits. If this is the case, there might not be any detectable effect in terms of our outcome variables. However, that would only bias our results downward.
} 
and unconstrained firms may be willing to absorb all the directed credit that they can get, constrained firms will use such credit to expand production, while unconstrained firms will primarily use it as a substitute for other borrowing. Their findings reveal that credit is used to finance more production, which implies an increase in the rate of growth of sales and profits; this provides evidence both of the existence of credit constraints and of the possibility of mitigating them through public credit.

Using firm level data, Bach (2008) analyzes whether the French loan programme Compte pour le Développement Industriel (CODEVI) succeeded in improving access to credit for small French firms. The results show that access to the financing subsidy substantially increased debt financing on the firm side. However, this did not lead to significant substitution between subsidized and unsubsidized financing channels, which can be taken as evidence of financial constraints. Finally, a close reference to our study is Lazzarini et al. (2015), where the authors analyze the effect of loans and equity instruments of BNDES on 286 Brazilian firms using data from the Sao Paulo Stock Exchange. Results show that BNDES's loans and equity allocation do not have a consistent effect on profitability, market valuation or investment decisions. These results run contrary to expectation, but should be taken with caution since these authors focus on a sample of firms traded on the stock exchange, which by their nature tend to be larger and less financially constrained than the overall population of firms receiving BNDES loans. Furthermore, the authors warn that although their results are inconsistent with the view that sees public credit as a mechanism to unlock productive investments, they do not find enough evidence to support the opposing perspective of public banks as a tool to help and rescue failed firms. ${ }^{4}$ In fact, Lazzarini et al. (2015) conclude that the most apparent problem with their sample of firms traded on the stock exchange is that they are not changing their investment decisions conditional on the new loans, probably because large firms could fund their projects with other sources of capital.

Regarding the effectiveness of credit programmes on firm performance, to our knowledge none of the extant studies rely on experimental designs. Instead, the empirical strategy is based on quasiexperimental methodologies that aim at mitigating selection biases that are pervasive in this context, since participation depends both on administrative eligibility criteria and individual decisions of the firms. The most common approach consists of applying difference-in-differences methods to a panel combined with matching techniques to ensure the similarity between participants and non-participants.

In a related survey, Hall and Maffioli (2008) offer a review of empirical evaluations in Latin America. According to the authors, studies reveal generally positive effects of credit programmes on intermediate outcomes like R\&D expenditures, worker training, and the introduction of new processes and quality control practices, especially in developing countries. However, the evidence of their effectiveness on longer-term performance outcomes like sales growth, exports, employment, labour productivity and total factor productivity (TFP) is mixed. For instance, Chudnovski, López, Rossi, and Ubfal (2005) analyze the Fondo Tecnológico Argentino (FONTAR) in Argentina, a programme aiming at improving R\&D and technology development through matching grants. They find positive effects of $57 \%$ to $79 \%$ on innovation investment, but find no significant impacts on labour productivity or new product sales. Similarly, for the case of Apoio ao Desenvolvimento Tecnológico da Empresa Nacional (ADTEN), a subsidy programme for R\&D and technological development in Brazil, De Negri, Borges Lemos, and De Negri (2006) find R\&D expenditures increase by $50 \%$ to $90 \%$, but identify no corresponding impact on sales, employment or labour productivity. Benavente, Crespi, and Maffioli (2007) study the Chilean Fondo Nacional de Desarrollo Tecnológico y Productivo (FONTEC), designed to promote technology transfer and development and R\&D support. The authors estimate a $40 \%$ increase in sales growth and 3\% increase in export intensity, although they find no impact on labour productivity in Chile.

\footnotetext{
${ }^{4}$ It could therefore be argued that these authors suggest a different form of credit misallocation with state-owned banks.
} 
Building on these results, Lopez-Acevedo and Tan (2010) provide a review of SME credit programmes in Mexico (Nafinsa, Bancomext, CONACyT, STPS and other programmes from the Ministry of Economy), Chile (SENCE, CORFO, PROCHILE, FONDEF), Colombia (FOMIPYME), and Peru (BONOPYME, PROMPYME, CITE). The authors report positive gains in sales, labour productivity and employment in Chile, and higher value added, sales, export and employment in Mexico. In Colombia, the results suggest positive effects on exports, investment in R\&D and TFP. Finally, in Peru, the findings show significant positive effects in sales and profits. Confirming the findings of Hall and Maffioli (2008), Lopez-Acevedo and Tan (2010) notice that some of the estimated effects take several years to materialize. Thus, they claim that the lack of impact of previous studies may be due to the short time range of the available databases, and emphasize the importance not only of controlling for potential selection biases but also accounting for time lags to correctly estimate the effects of credit programmes. Finally, based on the Pesquisa Industrial Anual (PIA) database from Instituto Brasileiro de Geografia e Estatística (IBGE), Ottaviano and Lage de Souza (2008) find no overall causal effect of BNDES Finem (Financing and Enterprises) R\&D loans on TFP. However, the authors argue that some association could be established.

\section{3 | PUBLIC CREDIT PROGRAMMES IN BRAZIL}

One important aspect of Latin American financial markets is that firms are likely to be credit constrained and to rely too heavily on their own sources to finance investment (Galindo \& Schiantarelli, 2003; Izquierdo, Micco and Olivera, 2005). For instance, using data from Doing Business from the World Bank, approximately $25 \%$ of firms consider themselves credit constrained in Colombia. In Brazil, using the Doing Business data from 2000-2003, Bond, Soderbon, and Wu (2007) estimate that about $40 \%$ of firms are credit constrained. This has detrimental implications for aggregate investment levels. Furthermore, Najberg, Pimentel Puga, and de Souza Oliveira (2000) argue that small businesses in Brazil operate with very elastic demand, facing high levels of competition, and usually lack managerial and investment resources to reach operational sustainability in the long run. Due to their fragile situation and elastic demand, many small firms need external financing to operate their business in the short run (Tasic, 2005).

Various factors contribute to generating credit constraints for micro, small and medium enterprises (MSMEs). From the demand side, these include their size, a lack of collateral and their technical deficiencies in managing and/or implementing sustainable investment projects. From the supply side, factors include limited medium- and long-term sources of funding in the domestic market and a lack of transparency and information to conduct proper credit risk assessments. The latter, in particular, reduces the appetite of banks to serve this specific market segment. Under this scenario, institutions such as BNDES in Brazil or Bancóldex in Colombia, with their access to domestic and foreign resources of medium- and long-term funding, would most certainly be easing credit constraints, improving investment levels and generating a more efficient allocation.

The main objective of public credit programmes is to support increased competitiveness and job creation in SMEs by channelling medium- and long-term financing for investments. Programme funds are typically used to finance fixed investments or permanent working capital associated with the execution of investment projects by qualifying SMEs. In Brazil, while BNDES is not the only source of public credit, it does represent one of the biggest outlays for machinery and equipment acquisition, accounting for $20 \%$ of all credit demand in the economy and 5\% of GDP. ${ }^{5}$ Many other public banks,

${ }^{5}$ BNDES finances $25 \%$ of all investment in manufacturing and infrastructure. 
such as regional development banks, act only as financial intermediaries to BNDES. For example, the other two large public banks, Banco do Brasil and Caixa, provide primarily agriculture credit and housing credit, respectively. 6

BNDES was founded in 1952 as an institutional innovation in the Brazilian banking system to fill an important gap: the provision of long-term loans for investment in manufacturing and infrastructure projects. Prior to this, the shortage of long-term bank loans was considered one of the most important barriers for economic development. Fully controlled by the Brazilian government, today BNDES is one of the largest development banks in the world. It offers many different credit lines, including export credit (BNDES-Exim), equity acquisition (Finem and BNDESPar) and machinery acquisition (Finame, Finame Leasing and BNDES Automático). Each line has its own lending policies that influence the interest rates charged. According to Musacchio and Lazzarini (2014), during the 1990s and 2000s the bank's equity business became its most profitable business line, helping Brazilian firms to finance capital investments when financial markets were still shallow. These credit lines are currently focused on supporting the discovery and the implementation of promising projects. BNDES (2015) reports that around $60 \%$ of the bank's total loans target firms with annual revenues above $\$ 130$ million.

BNDES loans have two important characteristics. First, BNDES loans are long term, generally up to 60 months. This is much longer than the duration of private sector credit in Brazil, which focuses almost exclusively on the short term. As documented by the OECD (2011), private banks have traditionally been unwilling to provide long-term funding and instead prefer to invest in relatively highyield short-term assets. ${ }^{7}$ The second characteristic is a favourable interest rate, relative to the cost of credit in Brazil. Segura-Ubiergo (2012) documents that until 2012 the interest rate on private market business loans in Brazil ranged between $30 \%$ and $50 \%$ per year. These figures are among the highest of any economy in the world. ${ }^{8}$ In contrast, BNDES funds have a three component cost: (1) the base interest rate, (2) the funding and credit risk spread, and (3) the financial intermediary spread. The main component is the base interest rate, known as the TJLP (Taxa de Juros de Longo Prazo, the Portuguese for 'federal long-term interest rate'), a government regulated long-term rate. The funding and credit risk spread is a component that varies by firm location, firm size and sector. The last part of interest rate charges depends on whether it is a large project or not (more than seven million Brazilian reals (R\$) until 2004 and R\$10 million after 2004).

Large projects are evaluated by BNDES itself (direct operations, operações diretas) and other projects are handled by financial intermediaries. As BNDES is a bank with no branches, it channels credit through regular and regional development banks. ${ }^{9}$ Furthermore, guarantees are required to access BNDES funding. In general, guarantees presented cover $130 \%$ of the loan value. Frequently, BNDES has temporary ownership of the equipment (garantia fiduciária) during the loan duration. ${ }^{10}$

\footnotetext{
$\overline{{ }^{6} \text { Additionally, FINEP is the Brazilian innovation agency, and provides public financing specifically for research and develop- }}$ ment projects for the entire science, technology and innovation system.

${ }^{7}$ This feature is not necessarily unique to Latin America, where thin markets for long-term bank finance are fairly common. More details can be found in OECD (2011).

${ }^{8}$ In such an environment a common criticism was that BNDES provided credit to productive sectors of the economy charging below market interest rates (Prochnik \& Machado, 2008; Lazzarini et al., 2015).

${ }^{9}$ Banks can also access BNDES funding and offer it to consumers. These funding sources are earmarked to machine acquisition or the specific credit line from BNDES and are marketed to the public as such. Credit risk is borne by the banks, as BNDES payments are not linked with firm loan defaults. Banks are also free to use their own credit scoring methods. In direct operations, the credit risk spread is $0.5 \%$ (medium and small firms are exempt since 2006). For loans through financial intermediaries, the spread is unlimited, but most operations use a $4 \%$ cap. This $4 \%$ cap allows the loan to qualify for a federal credit guarantee fund (FGPC) criteria.

${ }^{10}$ There are also fixed costs to apply for BNDES credit. The fixed costs can range from $1.0 \%$ to $2.0 \%$ of loan value in administrative costs and there is a $0.2 \%$ non-refundable application fee.
} 


\section{DATA DESCRIPTION}

For this study we exploit the richness of a unique panel data set that combines existing administrative and statistical information. ${ }^{11}$ Hence, the database is an unbalanced panel containing annual firm level information from 1997 to 2007. The main source of information is the Relação Anual de Informações Sociais (RAIS), an administrative file maintained by the Brazilian Ministry of Employment and Labour (Ministério do Trabalho e Emprego - MTE). Each year, all registered taxpaying establishments must send information to the Ministry on every worker who had been employed by the establishment anytime during the reference year. The RAIS provides a matched employer-employee longitudinal data set, similar to those available in developed countries. The novelty differential of these data is to combine the matched employer-employee structure with detailed information available on workers' occupation, wages and schooling. Thus, the main use of RAIS will be to provide the labour inputs variables as well as reliable information regarding the value of total exports of firms. The coverage of this database includes all firms that declare having hired workers in Brazil since 1996. For instance, in 2001, this represented more than 76 million workers declared in more than 230,000 firms from a variety of sectors. The panel data information allows classifying firms by activity, size, age of the firm, and region of activity.

Finally, to capture the beneficiaries of public credit in Brazilian firms, we benefitted from a novel database of public credit use compiled by the IPEA. This database has the foremost advantage of enabling a cross-reference of information using the unique firm identifier number (Cadastro Nacional de Pessoa Jurídica - CNPJ) of each firm with other databases at the firm level in Brazil. This information was available on an annual basis from 1997 to 2007.

There are two primary advantages of using a database with the characteristics described above. First, the large number of observations (firms) makes it statistically feasible to find firms that did not participate in the programme with similar characteristics to the ones that actually did (counterfactual). Second, the panel data structure allows for the controlling for non-observable effects that determine programme participation and firm performance. Nevertheless, the main disadvantage is that the RAIS database does not report information regarding total sales, and hence it is not possible to construct TFP measures. Still, it can be argued that total salary expenditure and total exports have a close relationship with firms' TFP. In principle, from basic production theory, a real wage indicator should be a measure of labour productivity. However, there are many arguments that challenge this view: for instance, the existence of collective wage agreements, special benefits for years worked in the firm, the existence of efficiency wages or the size of the firm. An interesting methodological suggestion given by Geary and Stark (2002) and Enflo, Henning, and Schön (2014) is the use of wage differentials as a proxy for labour productivity rather than average productivity measures. With this in mind, we construct a (standardized) measure of firms' wage differential, and we will follow the aforementioned authors to interpret it as an imperfect proxy for labour productivity at the firm level. Appendix 1 describes the construction of this variable.

Given the nature of the data and the fact that public credit programmes have been in place since before 1997, we needed to decide which year should represent the starting point for our analysis. In other words, these programmes would have been in place for years before the first year of the sample we consider (1997), and remain active throughout the entire sample. In order to evaluate the effectiveness of such an intervention, we need to consider an alternative starting point for the programmes. This decision is far from trivial and inevitably involves some discretion, but such a simplification should lead to an underestimation of the long-run effects of the use of public credit in Brazil. Assuming this caveat and its consequences, we decided to consider 2001 as the alternative starting point based

\footnotetext{
${ }^{11}$ The details and definitions of the variables used in the empirical analysis are explained in Appendix I.
} 
primarily on a statistical argument. ${ }^{12}$ Thus, all the firms that enter the programme before or after 2001 were excluded from the analysis. The decision is based on the fact that dividing the sample evenly at 2001 maximizes the statistical power of the analysis by placing an equal number of years before and after the chosen starting year. Needless to say, we interpret our results as a first, and therefore preliminary, analysis of the impact of such a programme. ${ }^{13}$

\section{5 | BASELINE CHARACTERISTICS}

Table 1 shows that, in 2001, public credit use comprises almost 17,000 firms, of which $23 \%$ were exporters. Almost a third of the beneficiary firms are producers of food and plastic, mainly concentrated in the south and south-east region. The vast majority (80\%) of such firms are micro and small sized.

TABLE 1 Descriptive statistics

\begin{tabular}{|c|c|c|c|c|}
\hline & \multicolumn{2}{|l|}{ Treated } & \multicolumn{2}{|l|}{ Controls } \\
\hline & Number & Distribution & Number & Distribution \\
\hline Firms & 16,700 & $100 \%$ & 215,183 & $100 \%$ \\
\hline Exporters & 3,786 & $23 \%$ & 6,963 & $3 \%$ \\
\hline Non-exporters & 12,914 & $77 \%$ & 208,220 & $97 \%$ \\
\hline \multicolumn{5}{|l|}{ Sectors: } \\
\hline Coal extraction & 9 & $0 \%$ & 80 & $0 \%$ \\
\hline Oil and natural gas extraction & 3 & $0 \%$ & 141 & $0 \%$ \\
\hline Metallic mineral extraction & 26 & $0 \%$ & 246 & $0 \%$ \\
\hline Non-metallic mineral extraction & 613 & $4 \%$ & 4,396 & $2 \%$ \\
\hline Foods and beverages & 2,826 & $17 \%$ & 31,725 & $15 \%$ \\
\hline Tobacco & 10 & $0 \%$ & 131 & $0 \%$ \\
\hline Textile & 693 & $4 \%$ & 8,440 & $4 \%$ \\
\hline Clothing and accessories & 600 & $4 \%$ & 33,971 & $16 \%$ \\
\hline Leather & 412 & $2 \%$ & 9,830 & $5 \%$ \\
\hline Wood products & 1,030 & $6 \%$ & 14,080 & $7 \%$ \\
\hline Paper products & 372 & $2 \%$ & 2,300 & $1 \%$ \\
\hline Edition and printing & 611 & $4 \%$ & 14,391 & $7 \%$ \\
\hline Petroleum refining & 86 & $1 \%$ & 129 & $0 \%$ \\
\hline Chemical products & 798 & $5 \%$ & 6,430 & $3 \%$ \\
\hline Rubber and plastic & 1,727 & $10 \%$ & 7,665 & $4 \%$ \\
\hline $\begin{array}{l}\text { Manufacture of non-metallic } \\
\text { minerals }\end{array}$ & 1,309 & $8 \%$ & 16,696 & $8 \%$ \\
\hline Basic metals & 510 & $3 \%$ & 4,173 & $2 \%$ \\
\hline Manufacture of metal products & 1,584 & $9 \%$ & 20,874 & $10 \%$ \\
\hline
\end{tabular}

(Continued)

\footnotetext{
${ }^{12}$ Considering alternative starting years does not change significantly our results.

${ }^{13}$ The effectiveness of public programmes could potentially depend on external factors that may vary with time. With this in mind, we made sure not to select a period particularly problematic for private lenders, since that could potentially bias our estimates.
} 
T A B L E 1 (Continued)

\begin{tabular}{|c|c|c|c|c|}
\hline & \multicolumn{2}{|l|}{ Treated } & \multicolumn{2}{|l|}{ Controls } \\
\hline & Number & Distribution & Number & Distribution \\
\hline Machinery and equipment & 1,205 & $7 \%$ & 8,378 & $4 \%$ \\
\hline Computer equipment & 31 & $0 \%$ & 420 & $0 \%$ \\
\hline Electric machinery and equipment & 301 & $2 \%$ & 2,927 & $1 \%$ \\
\hline Electronics & 99 & $1 \%$ & 1,294 & $1 \%$ \\
\hline $\begin{array}{l}\text { Medical equipment and precision } \\
\text { instruments }\end{array}$ & 138 & $1 \%$ & 1,591 & $1 \%$ \\
\hline $\begin{array}{l}\text { Fabrication and assembly of } \\
\text { automotive vehicles }\end{array}$ & 456 & $3 \%$ & 3,075 & $1 \%$ \\
\hline $\begin{array}{l}\text { Manufacture of transport } \\
\text { equipment }\end{array}$ & 48 & $0 \%$ & 952 & $0 \%$ \\
\hline Furniture & 1,156 & $7 \%$ & 20,028 & $9 \%$ \\
\hline Recycling & 47 & $0 \%$ & 820 & $0 \%$ \\
\hline \multicolumn{5}{|l|}{ Regions: } \\
\hline North & 385 & $2 \%$ & 5,645 & $3 \%$ \\
\hline North-east & 3,425 & $21 \%$ & 52,297 & $24 \%$ \\
\hline South-east & 6,593 & $39 \%$ & 82,592 & $38 \%$ \\
\hline South & 5,667 & $34 \%$ & 62,000 & $29 \%$ \\
\hline West & 630 & $4 \%$ & 12,649 & $6 \%$ \\
\hline \multicolumn{5}{|l|}{ Size (employment): } \\
\hline $\operatorname{Micro}(<5)$ & 2,151 & $13 \%$ & 121,013 & $56 \%$ \\
\hline Small (5-100) & 11,148 & $67 \%$ & 90,427 & $42 \%$ \\
\hline Medium (100-500) & 2,627 & $16 \%$ & 3,293 & $2 \%$ \\
\hline Large $(>500)$ & 774 & $5 \%$ & 450 & $0 \%$ \\
\hline \multicolumn{5}{|l|}{ Multinational: } \\
\hline No & 16,190 & $97 \%$ & 213,409 & $99 \%$ \\
\hline Yes & 510 & $3 \%$ & 1,774 & $1 \%$ \\
\hline
\end{tabular}

In Table 2 we present summary statistics for the outcomes and covariate variables prior to the beginning of the programme in 2001, for beneficiaries and non-beneficiaries of public credit. It can be seen that beneficiaries have systematically larger magnitudes in all variables (employment, total wage expenditure, total exports, total imports, total age of the firm, average credit size and average standardized wage) and their difference with non-beneficiaries is strongly significant. ${ }^{14}$ The information presented here is consistent with the previous Table and suggests that on average, firms that enter the programme are larger in size, spend more in wages, export and import more, are mature, take more public credit and have a higher average standardized wage. In fact, this could be reflecting the presence of unobserved factors affecting the participation decision. The identification strategy, explained below, will take into consideration these issues to find appropriate control firms and avoid biases generated by these unobserved factors.

\footnotetext{
${ }^{14}$ Appendix 1 presents a description of the variables used and its construction
} 
TA B LE 2 Descriptive statistics

\begin{tabular}{|c|c|c|c|c|c|c|}
\hline & \multicolumn{2}{|l|}{ Treated } & \multicolumn{2}{|l|}{ Controls } & \multicolumn{2}{|l|}{ t-test } \\
\hline & Average & St. Dev. & Average & St. Dev. & $\mathbf{T}$ & p-value \\
\hline Employment & 135 & 662 & 14 & 76 & 83.0 & 0.00 \\
\hline Salary expenditure (thou $\mathrm{R} \$$ ) & $2,749,683$ & $28,400,000$ & 188,421 & $2,448,082$ & 40.9 & 0.00 \\
\hline Exports (US\$) & $1,948,057$ & $32,800,000$ & 66,405 & $6,558,752$ & 26.0 & 0.00 \\
\hline Imports (US\$) & $1,453,841$ & $49,700,000$ & 76,486 & $4,716,537$ & 12.6 & 0.00 \\
\hline Age of the firm (years) & 14.95 & 1.86 & 1.44 & 7.59 & 2113.2 & 0.00 \\
\hline Public credit (thou R\$) & 940 & 18,455 & 0 & 0 & 23.1 & 0.00 \\
\hline Profits per worker (thou $\mathrm{R} \$$ ) & 0.04 & 0.51 & -0.08 & 0.68 & 92.1 & 0.00 \\
\hline
\end{tabular}

Furthermore, when inspecting the trends of the main outcomes (exports, employment and profits per worker) before the start year of the programme - between 1997 and 2000 - it can be seen that there is different behaviour on the part of treated and non-treated firms. Figures 1(a) to 1(c) show pre-treatment trends behaviour for exports, employment and average standardized wage. Although upon first inspection the pre-treatment performance between treated and non-treated firms may look alike, when performing a test of equality of trends, the null hypothesis of equality is rejected. ${ }^{15}$ This divergent performance could be due, among other factors, to the fact that the non-beneficiaries are a very heterogeneous group of firms and may not constitute an accurate comparison group for treated firms. Analyzing the effectiveness of the programme in this context will require finding an appropriate counterfactual to the beneficiary firms. This will be the first task of our identification strategy.

\section{I IDENTIFICATION STRATEGY}

We use the non-participating firms to estimate the counterfactual outcome of the beneficiary (treated) firms. However, as the previous section suggests, the pool of non-beneficiary (untreated) firms is not necessarily comparable to the group of beneficiaries, since getting public credit (treatment) was not randomly assigned, and hence potential issues of self-selection and administrative selection bias can arise and seriously compromise the validity of the estimations.

To avoid potential problems caused by selection bias we will use two methods: standard fixedeffects regressions and a combination of fixed effects with propensity score matching. If participation was determined by observable factors, these variables were included as control variables in a regression framework. However, some of these relevant factors are unobservable (for instance, entrepreneurial behaviour of the firm, manager characteristics, etc.), and thus cannot be accounted for. Nevertheless, the panel structure of the data allows us to eliminate all unobservable factors, as long as they do not vary with time, using a fixed-effects model.

More rigorously, we propose the following specification:

$$
\mathrm{Y}_{\mathrm{it}}=\alpha_{\mathrm{i}}+\mu_{\mathrm{t}}+\beta \mathrm{T}_{\mathrm{it}}+\gamma \mathrm{X}_{\mathrm{it}}+\varepsilon_{\mathrm{it}}
$$

where $Y_{\text {it }}$ is the outcome of the firm i in year $\mathrm{t}, \alpha_{\mathrm{i}}$ captures all time-constant factors that affect the outcome and are firm-specific, $\mu_{t}$ represents yearly shocks that affect all firms, $\mathrm{T}_{\text {it }}$ is a binary variable that takes the value 1 since the year in which the firm $i$ enters the programme, $X_{i t}$ is a vector of

${ }^{15}$ Tables available upon request. 
(a) Employment in logs (before matching)

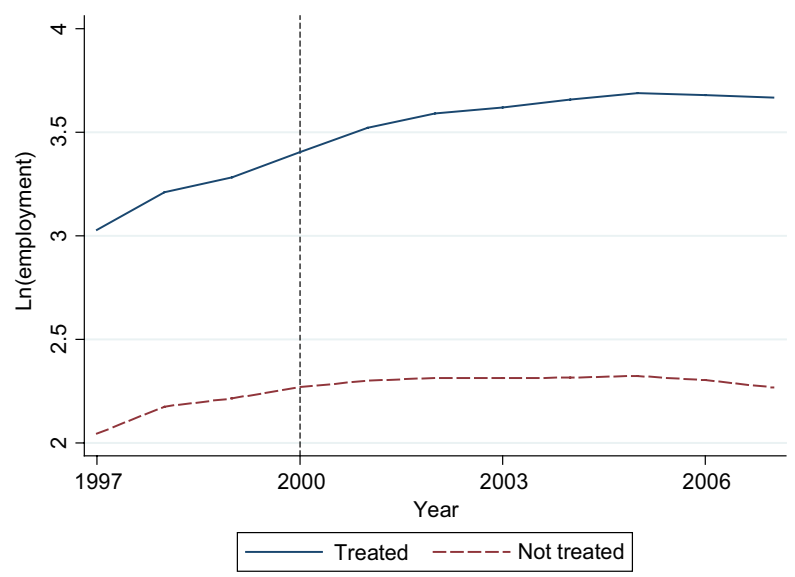

(b) Exports in logs (before matching)

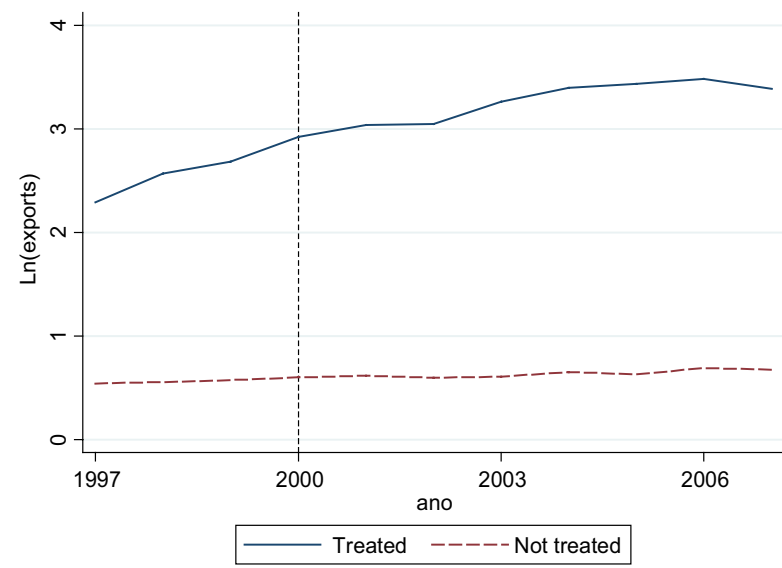

(c) Wage differential (before matching)

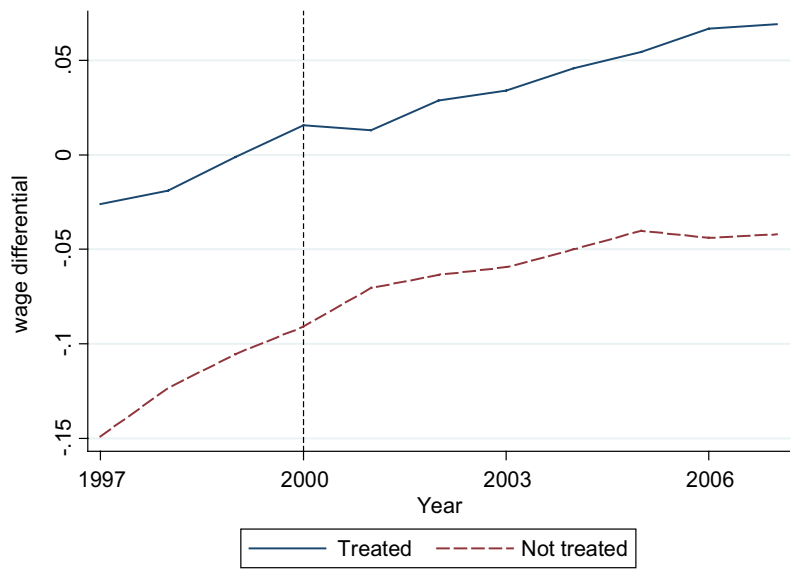

F I G U RE 1 Outcomes over time (before matching) [Colour figure can be viewed at wileyonlinelibrary.com] 
time-varying control variables, and $\varepsilon_{\mathrm{it}}$ is the usual error term assumed to be uncorrelated with $\mathrm{T}_{\mathrm{it}}$. The standard errors will be clustered at the firm level for the inference to be robust to within-firm correlation of the error terms. In absence of time-varying unobserved factors that affect both the outcome and the participation, the fixed-effects method leads to consistent estimator for $\beta$, the impact of the programme.

The validity of the difference-in-differences (fixed-effects) estimator rests on the identification assumption that trends in the outcomes would have been equal in absence of the treatment. However, this assumption may be difficult to accept when firms in the control group show different characteristics from participating firms. This is based on the idea that dissimilar firms are likely to follow different trends. In order to reinforce the results, we also run equation (1) on a matched sample, selecting among those firms in the comparison group that are more similar to beneficiaries, not only in terms of observed characteristics but also on their pre-treatment performance. By doing so, we ensure selection from the control group of only those firms with similar pre-treatment trends to those in the treated group.

More specifically, we define the previous year to treatment as a baseline year and estimate the conditional probability of participation, using a probit model:

$$
\mathrm{P}\left(\mathrm{T}_{\mathrm{it}}=1 \mid \mathrm{Z}_{\mathrm{it}}, \mathrm{Y}_{\mathrm{it}}^{\mathrm{l}}\right)=\Phi\left(\theta \mathrm{Z}_{\mathrm{it}}+\lambda \mathrm{Y}_{\mathrm{it}}^{\mathrm{l}}\right)
$$

for a fixed pre-treatment year $t$, where $\mathrm{Z}$ is a vector of covariates, $\mathrm{Y}^{1}$ is a vector of $\mathrm{k}$ lags of the outcome variable, $\left(\mathrm{Y}_{\mathrm{it}}-1, \ldots \mathrm{Y}_{\mathrm{it}}-\mathrm{k}\right)$, and $\Phi$ is the standard normal cumulative distribution function.

The main argument to match firms is to ensure that ex ante trends are similar between groups before the treatment. Thus, we use a separate probit model for each outcome. We claim that running separate probit models for each outcome is a more flexible strategy to find appropriate matches for each treated firm. Intuitively, for instance, a comparison firm may be a good match for a treated firm in terms of ex ante trends in exports but may follow a different dynamic in employment. Therefore, running separate probit models allows us to find better matches for each outcome. The main disadvantage of this choice is that the resulting control groups are different for each outcome, which may complicate the comparison of the results across outcomes. However, considering the importance of the parallel trends for our identification strategy and the validity of the estimations, we believe that the advantages of this choice outweigh its costs.

Using the predicted probability of participation, we match each treated firm with the untreated firm with most similar propensity score; we then drop from the database all the control group firms that are not matched to any treated firm and run equation (1) on this matched subsample.

\section{7 | ESTIMATION RESULTS}

First, we will discuss the full sample results, and then we will focus on the common support estimations.

\subsection{Full sample results}

This section summarizes the results obtained by estimating equation (1) using the fixed effects estimator for the three outcomes of interest: employment, total exports and wage differential, our proxy for labour productivity. The participation variable is a dummy that takes the value of 1 once the firm started participating in the public credit programme and 0 otherwise. 
Table 3 shows the impact of the programme on employment. Column 1 shows that, relative to the control group, the employment level of the beneficiary firms increased by $23 \%$ when only controlling for time dummies. ${ }^{16}$ Columns 2 and 3 show how this impact is robust to the inclusion of control variables and industry-year effects allowing for differential time trends across industry sectors. Thus, after controlling for observables, relative to the control group, the employment level of beneficiary firms increases by about $25 \%$. When interpreting these impacts we are taking into account the trajectories of the control and the treated group throughout the period of analysis. At the baseline, the matched sample of treated firms exhibit on average 100 employees per firm, hence a $23 \%$ increase implies an increase of 23 employees for the treated firms with respect to the control group.

T A B L E 3 Effects on employment (full sample)

\begin{tabular}{|c|c|c|c|}
\hline & (1) & (2) & (3) \\
\hline Public credit & $\begin{array}{c}0.2307 * * * \\
(0.020)\end{array}$ & $\begin{array}{c}0.2531 * * * \\
(0.018)\end{array}$ & $\begin{array}{c}0.2528 * * * \\
(0.018)\end{array}$ \\
\hline Age (in logs) & & $\begin{array}{c}0.8756 * * * \\
(0.016)\end{array}$ & $\begin{array}{c}0.8762 * * * \\
(0.016)\end{array}$ \\
\hline Years of schooling (in logs) & & $\begin{array}{c}0.1333 * * * \\
(0.008)\end{array}$ & $\begin{array}{c}0.1322 * * * \\
(0.008)\end{array}$ \\
\hline Average wage (in logs) & & $\begin{array}{c}0.1011 * * * \\
(0.007)\end{array}$ & $\begin{array}{c}0.1016 * * * \\
(0.007)\end{array}$ \\
\hline Patents (number) & & $\begin{array}{l}0.0055 \\
(0.004)\end{array}$ & $\begin{array}{l}0.0060 \\
(0.004)\end{array}$ \\
\hline Export good premium (dummy) & & $\begin{array}{c}0.1338 * * * \\
(0.008)\end{array}$ & $\begin{array}{c}0.1334 * * * \\
(0.008)\end{array}$ \\
\hline Imports (in logs) & & $\begin{array}{c}0.0212 * * * \\
(0.001)\end{array}$ & $\begin{array}{c}0.0211 * * * \\
(0.001)\end{array}$ \\
\hline Constant & $\begin{array}{c}2.2865 * * * \\
(0.002)\end{array}$ & $\begin{array}{c}-0.8945^{* * *} \\
(0.060)\end{array}$ & $\begin{array}{c}-0.9151 * * * \\
(0.060)\end{array}$ \\
\hline Fixed effects & $\checkmark$ & $\checkmark$ & $\checkmark$ \\
\hline Time dummies & $\checkmark$ & $\checkmark$ & $\checkmark$ \\
\hline Industry-year interactions & $x$ & $x$ & $\checkmark$ \\
\hline$R^{2}$ & 0.02 & 0.071 & 0.073 \\
\hline Obs. & 492,480 & 492,480 & 492,480 \\
\hline No. of firms & 49,248 & 49,248 & 49,248 \\
\hline
\end{tabular}

Cluster-robust standard errors in parentheses. *significant at 10\%; **ignificant at 5\%; ***significant at $1 \%$

Table 4 shows the impact of the programme on exports. The estimates show evidence of large impacts in all three specifications. Column 1 reveals a strongly significant positive impact of $47 \%$ on exports when controlling for time dummies. The estimated impact decreases after the addition of control variables, but remains large and significant (39\%). This effect is robust to the inclusion of industry-year interaction terms.

\footnotetext{
${ }^{16}$ More precisely, since the treatment variable is binary and the outcome is measured in logarithms, the correct way to interpret the coefficient is to calculate $\exp (\mathrm{b})-1$. However, the 'raw' coefficient is in most cases a very close approximation to the discrete impact, and hence we use what we consider the more straightforward way of interpreting the results.
} 
TA B LE 4 Effects on exports (full sample)

(1)

\begin{tabular}{|c|c|c|c|}
\hline Public credit & $\begin{array}{c}0.4765^{* * *} \\
(0.095)\end{array}$ & $\begin{array}{c}0.3880 * * * \\
(0.080)\end{array}$ & $\begin{array}{c}0.3896 * * * \\
(0.080)\end{array}$ \\
\hline Age (in logs) & & $\begin{array}{l}0.0449 \\
(0.038)\end{array}$ & $\begin{array}{l}0.0434 \\
(0.039)\end{array}$ \\
\hline Years of schooling (in logs) & & $\begin{array}{c}0.0347 * * * \\
(0.012)\end{array}$ & $\begin{array}{c}0.0338 * * * \\
(0.012)\end{array}$ \\
\hline Average wage (in logs) & & $\begin{array}{c}0.0395^{* * *} \\
(0.010)\end{array}$ & $\begin{array}{c}0.0399 * * * \\
(0.010)\end{array}$ \\
\hline Patents (number) & & $\begin{array}{c}-0.0082 \\
(0.017)\end{array}$ & $\begin{array}{c}-0.0075 \\
(0.017)\end{array}$ \\
\hline Export good premium (dummy) & & $\begin{array}{c}5.8490 * * * \\
(0.064)\end{array}$ & $\begin{array}{c}5.8482 * * * \\
(0.064)\end{array}$ \\
\hline Imports (in logs) & & $\begin{array}{c}0.0717 * * * \\
(0.004)\end{array}$ & $\begin{array}{c}0.0717 * * * \\
(0.004)\end{array}$ \\
\hline Constant & $\begin{array}{c}0.7106^{* * * *} \\
(0.007)\end{array}$ & $\begin{array}{c}-0.1515 \\
(0.115)\end{array}$ & $\begin{array}{c}-0.1544 \\
(0.115)\end{array}$ \\
\hline Fixed effects & $\checkmark$ & $\checkmark$ & $\checkmark$ \\
\hline Time dummies & $\checkmark$ & $\checkmark$ & $\checkmark$ \\
\hline Industry-year interactions & $x$ & $x$ & $\checkmark$ \\
\hline$R^{2}$ & 0.02 & 0.297 & 0.30 \\
\hline Obs. & 492,480 & 492,480 & 492,480 \\
\hline No. of firms & 49,248 & 49,248 & 49,248 \\
\hline
\end{tabular}

Cluster-robust standard errors in parentheses. *significant at 10\%; **significant at 5\%; ***significant at $1 \%$

Table 5 shows the impact of the programme on labour wage differential. According to the first set of estimations, none of the specifications detect a significant impact. This lack of impact might seem counterintuitive. However, a word of explanation is needed here. On the one hand, it is not theoretically clear that a positive effect is expected. For instance, Bustos' (2011) theoretical model argues that if credit lowers the marginal cost of the less productive technology (BNDES funds are mostly earmarked for domestic equipment purchases) more firms will adopt it and the aggregate productivity - proxy by the wage differential - may not increase. On the other hand, there could be a measurement problem. After all, this is a proxy that might not be capturing the entire dynamics of the firms, since wages may change more slowly than real labour productivity. Furthermore, our results are consistent with Ottaviano and Lage de Souza (2008) who find no overall effect of BNDES loans on TFP. Based on the PIA database, these authors suggest some association with productivity, but no causality is found.

\subsection{Construction of the matched sample}

Since beneficiary firms are not a random sample of the population, self-selection and administrative selection bias can arise (after all, BNDES loan application and selection depend on firm characteristics) and compromise the validity of our previous estimations. Thus, the evidence presented could be 
biased since we are not constructing a formal comparable counterfactual. We could even argue that the control group is very heterogeneous and thus not necessarily comparable to the treated firms. To reinforce the validity of the results, we will proceed to select - from the control group - those firms with similar observable characteristics to the treated firms. For this purpose, we use a matching methodology to pair each treated firm to the most similar untreated firm. Based on our data, we proceed in three steps. First, we estimate a probit model for the conditional probability of participation for each firm using a vector of observed characteristics as predictors. Second, we match each beneficiary with an untreated firm with the closest propensity score. Finally, we estimate equation (1) on the new matched sample, dropping all the untreated firms that are never used for comparison. The probit model is estimated one year before the treatment starts to ensure that none of the predictors are affected by the intervention. In addition to standard control variables - such as age and industry sector - we also include several lags of the outcome variable not only to match observable characteristics but also to ensure that treated and control firms followed similar pre-treatment paths. As described in the methodological section, this is a necessary condition for the difference-in-difference (fixed effects) estimator to be consistent. In particular, we estimate three different probit participation models to perform separate analyses for each outcome. In each one of these, we use four lags of the corresponding outcome variable to capture pre-treatment trends, plus a set of control variables.

TA B LE 5 Effects on wage differential (full sample)

\begin{tabular}{|c|c|c|c|}
\hline & (1) & (2) & (3) \\
\hline \multirow[t]{2}{*}{ Public credit } & -0.00002 & 0.0011 & 0.0016 \\
\hline & $(0.012)$ & $(0.009)$ & $(0.009)$ \\
\hline \multirow[t]{2}{*}{ Age (in logs) } & & $-0.1056^{* * *}$ & $-0.1079 * * *$ \\
\hline & & $(0.013)$ & $(0.013)$ \\
\hline \multirow[t]{2}{*}{ Years of schooling (in $\log s$ ) } & & 0.0004 & 0.0004 \\
\hline & & $(0.009)$ & $(0.009)$ \\
\hline \multirow[t]{2}{*}{ Average wage (in logs) } & & $0.6521 * * *$ & $0.6522 * * *$ \\
\hline & & $(0.020)$ & $(0.020)$ \\
\hline \multirow[t]{2}{*}{ Patents (number) } & & -0.0006 & -0.0006 \\
\hline & & $(0.002)$ & $(0.002)$ \\
\hline \multirow[t]{2}{*}{ Export good premium (dummy) } & & $-0.0147 * *$ & $-0.0147 * *$ \\
\hline & & $(0.006)$ & $(0.006)$ \\
\hline \multirow[t]{2}{*}{ Imports (in logs) } & & $-0.0048 * * *$ & $-0.0048 * * *$ \\
\hline & & $(0.001)$ & $(0.001)$ \\
\hline \multirow[t]{2}{*}{ Constant } & $-0.0403 * * *$ & $-4.4089 * * *$ & $-4.4116 * * *$ \\
\hline & $(0.002)$ & $(0.132)$ & $(0.132)$ \\
\hline Fixed effects & $\checkmark$ & $\checkmark$ & $\checkmark$ \\
\hline Time dummies & $\checkmark$ & $\checkmark$ & $\checkmark$ \\
\hline Industry-year interactions & $x$ & $x$ & $\checkmark$ \\
\hline$R^{2}$ & 0.007 & 0.255 & 0.255 \\
\hline Obs. & 492,480 & 492,480 & 492,480 \\
\hline No. of firms & 49,248 & 49,248 & 49,248 \\
\hline
\end{tabular}

Cluster-robust standard errors in parentheses. *significant at $10 \%$;*significant at $5 \%$; ***significant at $1 \%$ 
TA B LE 6 Participation model

\begin{tabular}{|c|c|c|c|}
\hline & Ln(employment) & Ln(exports) & wage differential \\
\hline$Y_{i t-1}$ & $\begin{array}{c}0.45^{* * * *} \\
(0.061)\end{array}$ & $\begin{array}{c}0.025 * * * \\
(0.008)\end{array}$ & $\begin{array}{c}0.01 \\
(0.05)\end{array}$ \\
\hline$Y_{i t-2}$ & $\begin{array}{c}-0.14 * \\
(0.08)\end{array}$ & $\begin{array}{c}0.005 \\
(0.009)\end{array}$ & $\begin{array}{l}-0.021 \\
(0.056)\end{array}$ \\
\hline$Y_{i t-3}$ & $\begin{array}{l}0.043 \\
(0.07)\end{array}$ & $\begin{array}{c}0.01 \\
(0.009)\end{array}$ & $\begin{array}{l}-0.005 \\
(0.058)\end{array}$ \\
\hline$Y_{i t-4}$ & $\begin{array}{l}-0.053 \\
(0.039)\end{array}$ & $\begin{array}{c}-0.017 * * \\
(0.008)\end{array}$ & $\begin{array}{c}0.023 \\
(0.045)\end{array}$ \\
\hline Age (in logs) & $\begin{array}{c}-0.173^{* * *} \\
(0.044)\end{array}$ & $\begin{array}{c}-0.109 * * * \\
(0.036)\end{array}$ & $\begin{array}{c}-0.103 * * * \\
(0.036)\end{array}$ \\
\hline Years of schooling (in logs) & $\begin{array}{c}0.258 * * * \\
(0.073)\end{array}$ & $\begin{array}{c}0.193 * * * \\
(0.071)\end{array}$ & $\begin{array}{c}0.185 * * * \\
(0.07)\end{array}$ \\
\hline Average wage (in logs) & $\begin{array}{c}0.134 * * * \\
(0.043)\end{array}$ & $\begin{array}{c}0.173 * * * \\
(0.042)\end{array}$ & $\begin{array}{c}0.177 * * * \\
(0.052)\end{array}$ \\
\hline Multinational (dummy) & $\begin{array}{c}-0.553 * * * \\
(0.11)\end{array}$ & $\begin{array}{c}-0.63 * * * \\
(0.11)\end{array}$ & $\begin{array}{c}-0.578 * * * \\
(0.11)\end{array}$ \\
\hline Patents (number) & $\begin{array}{c}0.039 \\
(0.035)\end{array}$ & $\begin{array}{l}0.059 * \\
(0.034)\end{array}$ & $\begin{array}{l}0.058 * \\
(0.034)\end{array}$ \\
\hline Export good premium (dummy) & $\begin{array}{c}0.154 * * * \\
(0.059)\end{array}$ & $\begin{array}{c}0.072 \\
(0.067)\end{array}$ & $\begin{array}{c}0.219 * * * \\
(0.06)\end{array}$ \\
\hline Imports (in logs) & $\begin{array}{c}0.02 * * * \\
(0.005)\end{array}$ & $\begin{array}{c}0.027 * * * \\
(0.005)\end{array}$ & $\begin{array}{c}0.031 * * * \\
(0.005)\end{array}$ \\
\hline Size of the firm (micro) & $\begin{array}{c}0.117 \\
(0.173)\end{array}$ & $\begin{array}{c}-1.117 * * * \\
(0.145)\end{array}$ & $\begin{array}{c}-1.089 * * * \\
(0.078)\end{array}$ \\
\hline Size of the firm (small) & $\begin{array}{c}0.329 * * \\
(0.148)\end{array}$ & $\begin{array}{c}-0.491 * * * \\
(0.136)\end{array}$ & $\begin{array}{c}-0.456 * * * \\
(0.062)\end{array}$ \\
\hline Size of the firm (medium) & $\begin{array}{l}0.239^{*} \\
(0.134)\end{array}$ & $\begin{array}{l}-0.097 \\
(0.132)\end{array}$ & $\begin{array}{l}0.161 \\
(0.13)\end{array}$ \\
\hline Constant & $\begin{array}{c}-4.279 * * * \\
(0.34)\end{array}$ & $\begin{array}{c}-3.133 * * * \\
(0.324)\end{array}$ & $\begin{array}{c}-3.003 * * * \\
(0.344)\end{array}$ \\
\hline Pseudo $R^{2}$ & 0.123 & 0.1035 & 0.1001 \\
\hline Obs. & 49,248 & 49,248 & 49,242 \\
\hline
\end{tabular}

Regressions control for geographical and industry dummies

*significant at $10 \%$;*significant at $5 \%$; ***significant at $1 \%$

The results of the probit models for 2001 are presented in Table 6. The dependent variable is dichotomous and takes the value of one if the firm borrowed from either BNDES or FINEP in 2001. From each individual probit model, we conclude that the more mature firms with the most skilled employees and the highest wage expenditures have a higher probability of participating in the public credit programme. Interestingly, small firms have a higher participation probability compared to the largest firms. This information is consistent with the summary statistics described above and gives 
(a) Employment in logs (matched sample)

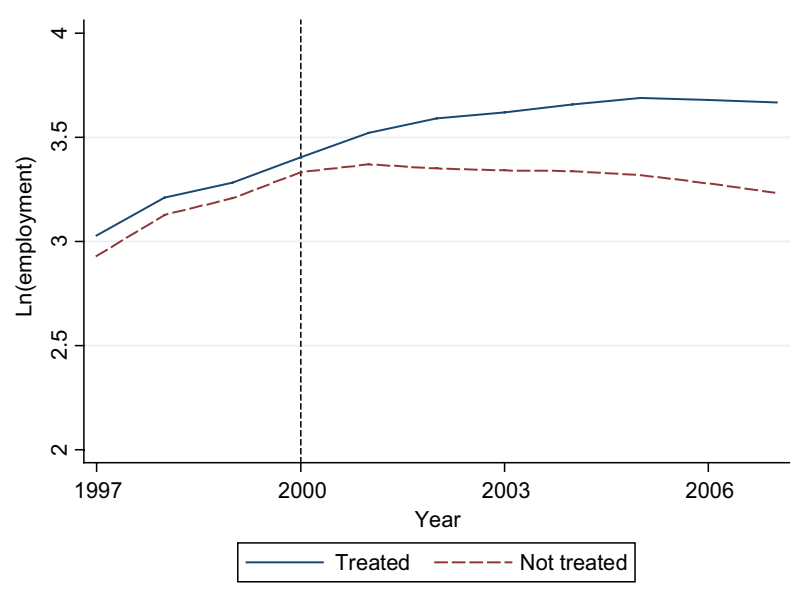

(b) Exports in logs (matched sample)

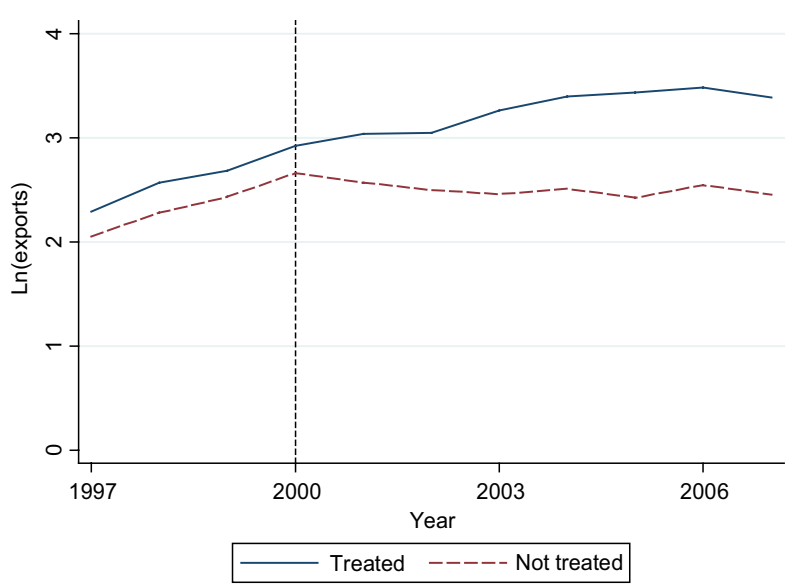

(c) Wage differential (matched sample)

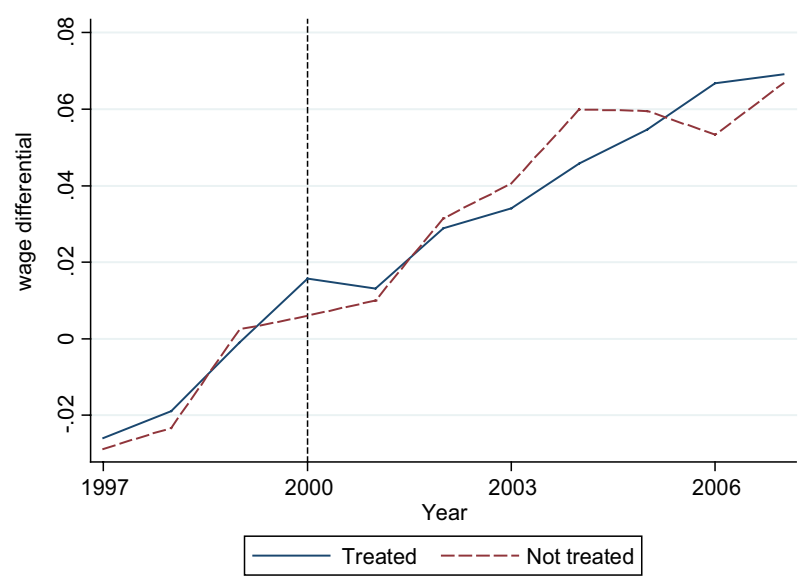

F I G U RE 2 Outcomes over time (after matching) [Colour figure can be viewed at wileyonlinelibrary.com] 
evidence of a participation bias. In other words, we need to control for this selection bias to be able to attribute the difference in outcomes between treated and non-treated firms to the programme. If we were to leave this issue unattained, the difference in outcomes may be given by the pre-treatment difference between treated and non-treated.

Using the probit models estimates, we compute the predicted probability of participation and match each beneficiary with the non-beneficiary (with the closest propensity score). We construct this control group using the one-nearest-neighbour algorithm. Finally, we drop from our sample all the control firms that are not matched to any treated firm. Appendix 2 shows the balancing test for the covariates included in each participation equation considering a control group defined by the matching procedure. Figures 2(a) to 2(c) show the three outcomes of interest for treated and control firms after the matching procedure.

As expected, after the matching procedure, the hypothesis of equality of means of observable characteristics for both treated and untreated firms cannot be rejected. In sum, both the graphical evidence and the statistical tests suggest that the matching is successful in constructing a control group that is very similar to the treated group. Once these characteristics (including the pre-treatment trends) between participating and non-participating firms are balanced, the implicitly defined common support is free from selection bias and we can thus attribute the difference to the program participation. The final step is to estimate specification (1) in this new matched sample, the common support.

\section{3 | Matched sample results}

Tables 7 to 9 present the results of the estimation over the common support. Interestingly enough, the results for the matched sample are very similar to the ones for the full sample. More specifically, we find that relative to the control group, beneficiary firms increased their employment and value of total exports by $24 \%$ and $40 \%$, respectively, while we find no significant impact on average wage differential.

An interesting effect could be behind the analysis for exports. In fact, our export estimates could be mixing two distinct possible effects: on the one hand, the programme may increase total export volumes, but on the other hand it could also change the pool of exporting firms by inducing firms (that were not exporters) to start exporting. To address this issue, we perform two separate analyses. First, we study the impact of the programme on the probability of a firm being an exporter, using as the outcome of interest a binary variable that takes the value one when the firm has non-zero exports. To estimate this specification, we use a linear probability model. Such a model has some limitations with respect to its close-related probit or logit, mainly the fact that marginal effects are constant. ${ }^{17}$ However, it has the advantage of controlling for fixed effects. The results of these estimations are presented in Table 10 .

It can be argued that an increase in the probability of exporting - that is, firms that move from non-exporter to exporter - would be evidence of firms that were able to overcome credit constraints and gain access to financial markets. In other words, the most productive firms are those that benefitted from the programme and increased their productivity by getting access to financial markets. Interestingly enough, as Table 10 shows, we find no significant impact on the probability of exporting. This finding suggests that the positive impact found in the previous estimations is mainly driven by the increase in total export volumes among firms that were already exporting. To further test this hypothesis, we then analyze the effect of the public credit programme on export volumes by restricting the sample to firms that were (already) exporters two years previous to treatment. These results are

\footnotetext{
${ }^{17}$ Another drawback of the linear probability model is that it does not guarantee that the predicted probability to be between zero and one, although this is irrelevant in this case where the estimates are not used for prediction.
} 
presented in Table 11. The findings reveal very large and significant impacts: relative to the control group and among exporting firms, beneficiaries doubled their total exports value. These estimates support the hypothesis that the effect on exports is almost entirely driven by the increase in export volumes among exporting firms, while not affecting the probability of becoming an exporter.

T A B LE 7 Effects on employment (matched sample)

\begin{tabular}{|c|c|c|c|}
\hline & (1) & (2) & (3) \\
\hline \multirow[t]{2}{*}{ Public credit } & $0.2462 * * *$ & $0.2404 * * *$ & $0.2395 * * *$ \\
\hline & (0.029) & $(0.026)$ & $(0.026)$ \\
\hline \multirow[t]{2}{*}{ Age (in logs) } & & $1.1563 * * *$ & $1.1577 * * *$ \\
\hline & & $(0.090)$ & $(0.091)$ \\
\hline \multirow[t]{2}{*}{ Years of schooling (in logs) } & & 0.0186 & 0.0201 \\
\hline & & $(0.075)$ & $(0.075)$ \\
\hline \multirow[t]{2}{*}{ Average wage (in logs) } & & -0.0197 & -0.0229 \\
\hline & & $(0.088)$ & $(0.087)$ \\
\hline \multirow[t]{2}{*}{ Patents (number) } & & 0.0049 & 0.0061 \\
\hline & & $(0.010)$ & (0.010) \\
\hline \multirow[t]{2}{*}{ Export good premium (dummy) } & & $0.1085 * * *$ & $0.1076 * * *$ \\
\hline & & $(0.027)$ & $(0.027)$ \\
\hline \multirow[t]{2}{*}{ Imports (in logs) } & & $0.0262 * * *$ & $0.0262 * * *$ \\
\hline & & $(0.004)$ & $(0.004)$ \\
\hline \multirow[t]{2}{*}{ Constant } & $3.1698 * * *$ & 0.1734 & 0.1944 \\
\hline & $(0.014)$ & $(0.611)$ & $(0.604)$ \\
\hline Fixed effects & $\checkmark$ & $\checkmark$ & $\checkmark$ \\
\hline Time dummies & $\checkmark$ & $\checkmark$ & $\checkmark$ \\
\hline Industry-year interactions & $x$ & $x$ & $\checkmark$ \\
\hline$R^{2}$ & 0.09 & 0.171 & 0.176 \\
\hline Obs. & 15,700 & 15,700 & 15,700 \\
\hline No. of firms & 1,570 & 1,570 & 1,570 \\
\hline
\end{tabular}

Cluster-robust standard errors in parentheses. *significant at 10\%; **significant at 5\%; ***significant at $1 \%$

Overall, the results for the matched sample confirm our previous findings; we find positive and large impacts of the public credit policy on employment and total exports. Interestingly, the impact on exports is driven by the increase in export volumes among exporting firms and not by changes in the pool of exporting firms. In the case of our measure of proxy for productivity - wage differential results do not show any significant impact.

We now carefully analyze the dynamic pattern of the effects of the public credit programme. In other words, the interest is to disentangle the effects of the programme to understand how they vary over time. We modify our econometric specification by replacing the treatment variable with a dummy variable $D_{i t}$ that takes the value 1 in the first year of treatment and 0 otherwise. We will also use several lags of this variable, $D_{i t-k}$, to indicate the impact of the intervention in the $k$-th year of treatment. Table 12 shows the results for the three outcomes of interest.

We find that the impact on employment is always significant and increases over time, from a magnitude of about $14 \%$ in the first year after the treatment up to $32 \%$ after six years of treatment. 
Figure 3(a) shows these effects and their corresponding standard errors. Our findings show a strong and significant positive trend effect of the public credit programme.

TA B LE 8 Effects on exports (matched sample)

\begin{tabular}{|c|c|c|c|}
\hline & (1) & (2) & (3) \\
\hline Public credit & $\begin{array}{c}0.5358 * * * \\
(0.119)\end{array}$ & $\begin{array}{c}0.4060 * * * \\
(0.102)\end{array}$ & $\begin{array}{c}0.3979 * * * \\
(0.102)\end{array}$ \\
\hline Age (in logs) & & $\begin{array}{l}0.0073 \\
(0.309)\end{array}$ & $\begin{array}{c}-0.0014 \\
(0.312)\end{array}$ \\
\hline Years of schooling (in logs) & & $\begin{array}{c}-0.1072 \\
(0.184)\end{array}$ & $\begin{array}{c}-0.1191 \\
(0.184)\end{array}$ \\
\hline Average wage (in logs) & & $\begin{array}{c}0.2976 * \\
(0.159)\end{array}$ & $\begin{array}{c}0.2987 * \\
(0.160)\end{array}$ \\
\hline Patents (number) & & $\begin{array}{l}0.0931 \\
(0.076)\end{array}$ & $\begin{array}{l}0.0975 \\
(0.075)\end{array}$ \\
\hline Export good premium (dummy) & & $\begin{array}{c}4.4198 * * * \\
(0.213)\end{array}$ & $\begin{array}{c}4.4214 * * * \\
(0.212)\end{array}$ \\
\hline Imports (in logs) & & $\begin{array}{c}0.0913 * * * \\
(0.015)\end{array}$ & $\begin{array}{c}0.0912 * * * \\
(0.014)\end{array}$ \\
\hline Constant & $\begin{array}{c}2.4279 * * * \\
(0.060)\end{array}$ & $\begin{array}{c}-0.1550 \\
(1.374)\end{array}$ & $\begin{array}{c}-0.0874 \\
(1.373)\end{array}$ \\
\hline Fixed effects & $\checkmark$ & $\checkmark$ & $\checkmark$ \\
\hline Time dummies & $\checkmark$ & $\checkmark$ & $\checkmark$ \\
\hline Industry-year interactions & $x$ & $x$ & $\checkmark$ \\
\hline$R^{2}$ & 0.01 & 0.208 & 0.21 \\
\hline Obs. & 15,800 & 15,800 & 15,800 \\
\hline No. of firms & 1,580 & 1,580 & 1,580 \\
\hline
\end{tabular}

Cluster-robust standard errors in parentheses. *significant at 10\%; ** significant at 5\%; *** significant at $1 \%$

In the case of total exports, the impact clearly increases over time, but it takes more time to materialize. In the first year, the positive estimate is not significant, but immediately becomes significant after the second year of the programme. Figure 3(b) shows that the dynamic impact exhibits an inverted U-shape, increasing during most of the years but slightly decreasing in the last one suggesting the existence of an optimal duration of the treatment. Consistent with our previous results, wage differential does not exhibit any significant dynamic pattern. The third column of Table 12 shows that none of the estimates associated with the treatment are significant.

\section{CONCLUDING REMARKS}

Our study contributes to the growing debate on the role of public credit programmes and stateowned development banks in promoting the performances of firms. In particular, our article sheds light on the effectiveness of public credit programmes in Brazil by using a unique micro-level panel data set compiled by the IPEA, which includes information on both firm-level performances and 
access to public credit lines for more than 231,000 firms. We focus on the impact of the credit lines managed by BNDES and FINEP in fostering employment, labour productivity and export labour. We find that access to public credit lines has a significant and robust positive impact on employment and exports, while we do not find evidence of a significant effect on wage differential, our proxy for productivity. Interestingly enough, our findings show that the impact on exports is mainly driven by the increase in export volumes among exporting firms, while we do not find a significant effect on the probability of becoming an exporter. These results suggest that the analyzed public credit programmes effectively foster firms' growth and helped exporters maintain and increase their operations. However, we do not find conclusive evidence of productivity gains. These results are consistent with Ottaviano and Lage de Souza (2008) who find no overall effect of BNDES Finem loans on TFP. Based on the PIA database, these authors suggest some association with productivity, but no causality is found.

T A B LE 9 Effects on wage differential (matched sample)

\begin{tabular}{|c|c|c|c|}
\hline & (1) & (2) & (3) \\
\hline \multirow[t]{2}{*}{ Public credit } & -0.0054 & -0.0063 & -0.0067 \\
\hline & $(0.015)$ & $(0.012)$ & $(0.012)$ \\
\hline \multirow[t]{2}{*}{ Age (in logs) } & & $-0.1051^{*}$ & $-0.1082^{*}$ \\
\hline & & $(0.056)$ & $(0.056)$ \\
\hline \multirow[t]{2}{*}{ Years of schooling (in logs) } & & $0.1374 * * *$ & $0.1367 * * *$ \\
\hline & & $(0.051)$ & $(0.051)$ \\
\hline \multirow[t]{2}{*}{ Average wage (in logs) } & & $0.8182 * * *$ & $0.8186^{* * *}$ \\
\hline & & $(0.143)$ & $(0.143)$ \\
\hline \multirow[t]{2}{*}{ Patents (number) } & & -0.0089 & -0.0084 \\
\hline & & $(0.009)$ & $(0.009)$ \\
\hline \multirow[t]{2}{*}{ Export good premium (dummy) } & & -0.0275 & -0.0276 \\
\hline & & $(0.019)$ & $(0.019)$ \\
\hline \multirow[t]{2}{*}{ Imports (in logs) } & & $-0.0057^{* *}$ & $-0.0058 * *$ \\
\hline & & $(0.003)$ & $(0.003)$ \\
\hline \multirow[t]{2}{*}{ Constant } & $0.0708 * * *$ & $-5.3923 * * *$ & $-5.3580 * * *$ \\
\hline & $(0.014)$ & $(0.838)$ & $(0.838)$ \\
\hline Fixed effects & $\checkmark$ & $\checkmark$ & $\checkmark$ \\
\hline Time dummies & $\checkmark$ & $\checkmark$ & $\checkmark$ \\
\hline Industry-year interactions & $x$ & $x$ & $\checkmark$ \\
\hline$R^{2}$ & 0.009 & 0.323 & 0.324 \\
\hline Obs. & 15,790 & 15,790 & 15,790 \\
\hline No. of firms & 1,579 & 1,579 & 1,579 \\
\hline
\end{tabular}

Cluster-robust standard errors in parentheses. *significant at 10\%; **significant at 5\%; ***significant at $1 \%$

Nevertheless, some caution is probably needed when interpreting this lack of effect on productivity - for example, the result may be driven by the specific indicator we are using rather than being due to a real lack of impact. In fact, one would expect a simultaneous increase of export and employment to be accompanied by improvements in productivity. Unfortunately, due to data limitations, we cannot compute a standard measure of productivity based on the RAIS database. For that purpose, the PIA 
from IBGE should be used with the consequent loss of observations. This is certainly a task for future research provided that new and better data become available.

TA B LE 10 Impact on the probability of exporting (matched sample)

\begin{tabular}{|c|c|c|c|}
\hline & (1) & (2) & (3) \\
\hline \multirow[t]{2}{*}{ Public credit } & $0.0197 *$ & 0.0108 & 0.0112 \\
\hline & $(0.011)$ & $(0.009)$ & $(0.009)$ \\
\hline \multirow[t]{2}{*}{ Age (in logs) } & & -0.0007 & -0.0015 \\
\hline & & $(0.027)$ & $(0.027)$ \\
\hline \multirow[t]{2}{*}{ Years of schooling (in logs) } & & -0.0112 & -0.0120 \\
\hline & & $(0.017)$ & $(0.017)$ \\
\hline \multirow[t]{2}{*}{ Average wage (in logs) } & & 0.0144 & 0.0147 \\
\hline & & $(0.011)$ & $(0.011)$ \\
\hline \multirow[t]{2}{*}{ Patents (number) } & & 0.0038 & 0.0045 \\
\hline & & $(0.004)$ & $(0.004)$ \\
\hline \multirow[t]{2}{*}{ Export good premium (dummy) } & & $0.4506^{* * *}$ & $0.4510 * * *$ \\
\hline & & $(0.019)$ & $(0.019)$ \\
\hline \multirow[t]{2}{*}{ Imports (in logs) } & & $0.0068 * * *$ & $0.0068 * * *$ \\
\hline & & $(0.001)$ & $(0.001)$ \\
\hline \multirow[t]{2}{*}{ Constant } & $0.1984 * * *$ & 0.0690 & 0.0702 \\
\hline & $(0.006)$ & $(0.114)$ & $(0.114)$ \\
\hline Fixed effects & $\checkmark$ & $\checkmark$ & $\checkmark$ \\
\hline Time dummies & $\checkmark$ & $\checkmark$ & $\checkmark$ \\
\hline Industry-year interactions & $x$ & $x$ & $\checkmark$ \\
\hline$R^{2}$ & 0.005 & 0.224 & 0.227 \\
\hline Obs. & 15,830 & 15,830 & 15,830 \\
\hline No. of firms & 1,583 & 1,583 & 1,583 \\
\hline
\end{tabular}

Cluster-robust standard errors in parentheses. *significant at 10\%; **significant at 5\%; ***significant at $1 \%$

Our study finds a positive effect of the public credit policy effect of BNDES and FINEP which could be seen as running contrary to Lazzarini et al. (2015). However, care needs to be taken when comparing both studies, since Lazzarini et al. (2015) analyze different outcomes and, most importantly, have a smaller sample size with larger firms. They conclude that BNDES's loans and equity allocation do not have a consistent effect on profitability, market valuation or investment decisions, but they focus on a sample of firms (traded on the stock exchange) which tend to be larger and less financially constrained than the overall population of firms receiving BNDES loans.

Because of the relevance and size of the state-owned banks in Brazil, our findings offer a valuable contribution to the debate on which policy instruments should be used to support the development of a competitive productive system in emerging countries. Sound and wide access to credit has always been considered a key ingredient of any private sector development strategy. Our results show that the provision of credit through public programmes in Brazil plays a significant role in making credit available for firms and effectively improves firms' competitiveness, particularly when measured in terms of volume of exports. Our results should also be interpreted within the context of our period of analysis: 2000 to 2007. 
T A B L E 11 Impact on the quantity exported (matched sample)

(1)

$\begin{array}{cc}\text { Public credit } & 1.1504^{* * * *} \\ & (0.374)\end{array}$

Age (in logs)

Years of schooling (in logs)

Average wage (in logs)

Patents (number)

Export good premium (dummy)

Imports (in logs)

\begin{tabular}{lccc} 
& & $(0.032)$ & $(0.032)$ \\
\hline Constant & $11.0240^{* * *}$ & 2.8974 & 2.8140 \\
& $(0.207)$ & $(5.797)$ & $(5.818)$ \\
\hline Fixed effects & $\checkmark$ & $\checkmark$ & $\checkmark$ \\
Time dummies & $\boldsymbol{X}$ & $\boldsymbol{X}$ & $\checkmark$ \\
\hline Industry-year interactions & $\mathbf{X}$ & 0.190 & $\checkmark$ \\
\hline$R^{2}$ & 0.057 & 3,140 & 3,140 \\
\hline Obs. & 3,140 & 314 & 314 \\
\hline No. of firms & 314 & & \\
\hline
\end{tabular}

Cluster-robust standard errors in parentheses. *significant at $10 \% ; * *$ significant at $5 \%$; ***significant at $1 \%$

(2)

(3)

$1.0086^{* * * *}$

(0.338)

$1.0073 * * *$

(0.338)

$-1.1934$

$-1.0868$

(1.449)

(1.458)

0.3043

0.4070

(0.995)

(0.991)

0.9161 **

$0.8149 *$

(0.434)

(0.424)

$-0.0376$

$-0.0430$

(0.094)

(0.090)

$2.5402 * * *$

2.5346 ***

(0.221)

0.1358 ***

(0.032)

2.8140

.818)

This article also contributes to the production of evidence on the effectiveness of programmes aimed at supporting firm-level performances. In particular, the data setting not only allows us to reduce selection bias by controlling for firm-level fixed effects, but also improves the credibility of the difference-in-difference assumption by matching treated and control groups on the pre-treatment trends of the outcome variables. Because administrative datasets with similar characteristics to the one we used are becoming available, our estimation strategy contributes to the methodological discussion.

Our contribution spurs new avenues of potential research. First, as suggested above, since a standard measure of productivity could not be computed given the dataset used in this article, a natural extension is the inclusion of such a measure. Under special circumstances, firm-level data for the manufacturing sector are available in Brazil. Second, future research should also expand the analysis beyond average treatment effects. If more detailed information about the characteristics of the credit lines becomes available, the analysis could include the heterogeneous effects that access to public credit lines may have in terms of loan terms, targeted firms' populations and other specific requirements of the credit lines. A third avenue of potential research comprises improving our understanding of the relationship between credit conditions and firm performance. This would allow controlling not only by firm-level pre-treatment economic performances (which under reasonable 
assumptions could be consider a good proxy of a firm's financial health), but also by firm-level financial characteristics.

TA B LE 12 Dynamic effects (matched sample)

\begin{tabular}{|c|c|c|c|}
\hline & Ln(employment) & Ln(exports) & wage differential \\
\hline \multirow[t]{2}{*}{$D_{t}$} & $0.1373 * * *$ & 0.1191 & 0.0016 \\
\hline & $(0.019)$ & $(0.117)$ & $(0.014)$ \\
\hline \multirow[t]{2}{*}{$D_{t-1}$} & $0.1838 * * *$ & $0.3923 * * *$ & -0.0089 \\
\hline & $(0.024)$ & $(0.119)$ & $(0.013)$ \\
\hline \multirow[t]{2}{*}{$D_{t-2}$} & $0.2201 * * *$ & $0.4076^{* * *}$ & -0.0123 \\
\hline & $(0.027)$ & $(0.127)$ & $(0.013)$ \\
\hline \multirow[t]{2}{*}{$D_{t-3}$} & $0.2774 * * *$ & $0.5646 * * *$ & -0.0095 \\
\hline & $(0.031)$ & $(0.140)$ & $(0.015)$ \\
\hline \multirow[t]{2}{*}{$D_{t-4}$} & $0.2971 * * *$ & $0.5262 * * *$ & 0.0084 \\
\hline & $(0.036)$ & $(0.140)$ & $(0.018)$ \\
\hline \multirow[t]{2}{*}{$D_{t-5}$} & $0.3227 * * *$ & $0.3787 * * *$ & -0.0198 \\
\hline & $(0.042)$ & $(0.140)$ & $(0.026)$ \\
\hline \multirow[t]{2}{*}{ Age (in logs) } & $1.1604 * * *$ & 0.0015 & $-0.1083 *$ \\
\hline & $(0.091)$ & $(0.312)$ & $(0.056)$ \\
\hline \multirow[t]{2}{*}{ Years of schooling (in logs) } & 0.0175 & -0.1267 & $0.1370 * * *$ \\
\hline & $(0.075)$ & $(0.184)$ & $(0.051)$ \\
\hline \multirow[t]{2}{*}{ Average wage (in logs) } & -0.0256 & $0.2955^{*}$ & $0.8188^{* * *}$ \\
\hline & $(0.087)$ & $(0.159)$ & $(0.143)$ \\
\hline \multirow[t]{2}{*}{ Patents (number) } & 0.0063 & 0.0991 & -0.0085 \\
\hline & $(0.009)$ & $(0.074)$ & $(0.009)$ \\
\hline \multirow[t]{2}{*}{ Export good premium (dummy) } & $0.1079 * * *$ & $4.4214 * * *$ & -0.0275 \\
\hline & $(0.027)$ & $(0.212)$ & $(0.019)$ \\
\hline \multirow[t]{2}{*}{ Imports (in logs) } & $0.0261 * * *$ & $0.0914 * * *$ & $-0.0058 * *$ \\
\hline & $(0.004)$ & $(0.014)$ & $(0.003)$ \\
\hline \multirow[t]{2}{*}{ Constant } & 0.2139 & -0.0555 & $-5.3758 * * *$ \\
\hline & $(0.605)$ & $(1.370)$ & $(0.839)$ \\
\hline Fixed effects & $\checkmark$ & $\checkmark$ & $\checkmark$ \\
\hline Time dummies & $\checkmark$ & $\checkmark$ & $\checkmark$ \\
\hline Industry-year interactions & $\checkmark$ & $\checkmark$ & $\checkmark$ \\
\hline$R^{2}$ & 0.18 & 0.211 & 0.324 \\
\hline Obs. & 15,700 & 15,800 & 15,790 \\
\hline No. of firms & 1,570 & 1,580 & 1,579 \\
\hline
\end{tabular}

Cluster-robust standard errors in parentheses. *significant at 10\%; **significant at 5\%; ***significant at $1 \%$ 
(a) Employment

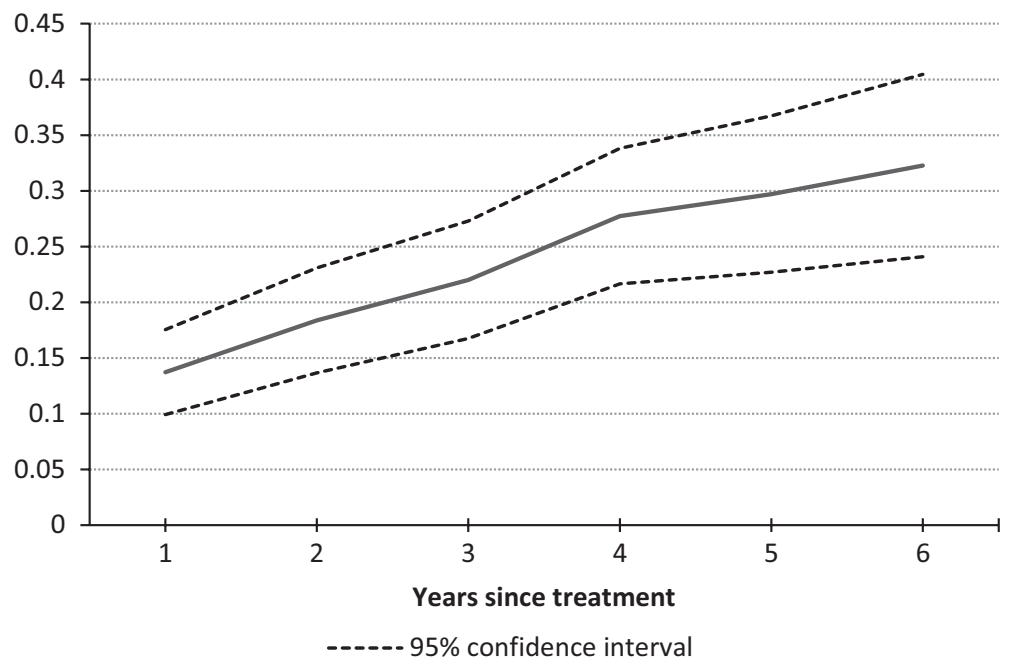

(b) Exports

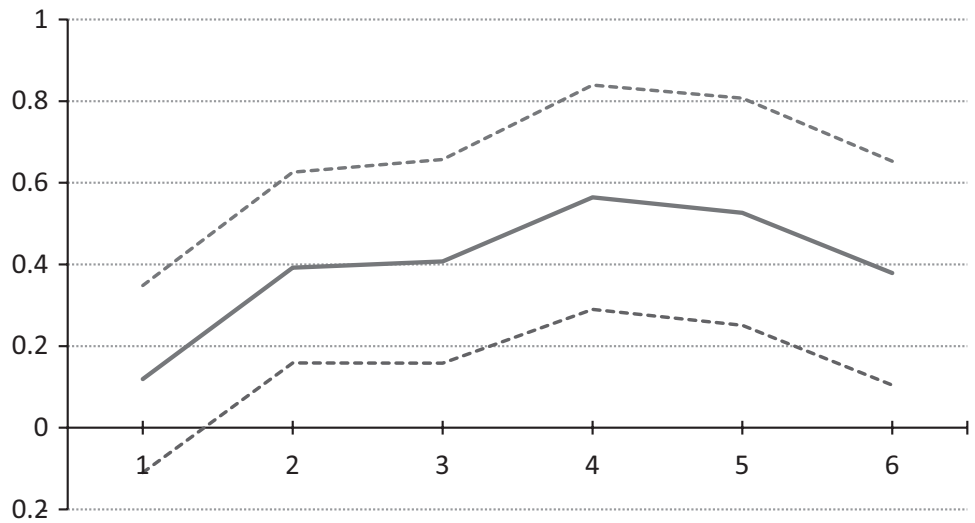

Years since treatment

95\% confidence interval

F IG U RE 3 Dynamic impacts (matched sample)

\section{REFERENCES}

Aivazian, V., \& Santor, E. (2008). Financial constraints and investment: Assessing the impact of a World Bank loan program on small and medium-sized enterprises in Sri Lanka. Canadian Journal of Economics/Revue canadienne d'économique, 41, 475-500.

Amsden, A. H. (1989). Asia's next giant: South Korea and late industrialization. New York: Oxford University Press.

Amsden, A. H. (2001). The rise of 'the rest': Challenges to the West from late-industrializing economies. Oxford: Oxford University Press.

Armendáriz de Aghion, B. (1999). Development banking. Journal of Development Economics, 58, 83-100.

Aronovich, S., \& Fernandes, A. G. (2006). A atuação do governo no mercado de crédito: Experiências de IFDs em países desenvolvidos. Revista do BNDES, 13(25), 3-34.

Bach, L. (2008, January). Are small and medium-sized firms really credit constrained? Evidence from a French targeted credit programme. Paper presented at CESifo Conference 'Financial Market Regulation in Europe', Munich. Retrieved from https://www.cesifo-group.de/portal/pls/portal/!PORTAL.wwpob_page.show?_docname=1003988.PDF. 
Bass, T., \& Schrooten, M. (2006). Relationship banking and SMEs: A theoretical analysis. Small Business Economics, 27(2), 127-137.

Banerjee, A., \& Duflo, E. (2014). Do firms want to borrow more? Testing credit constraints using a directed lending program. The Review of Economic Studies, 81(2), 572-607.

Beck, T., Demirgüç-Kunt, A., \& Maksimovic, V. (2005). Financial and legal constraints to growth: Does firm size matter? The Journal of Finance, 60(1), 37-177.

Bellone, F., Musso, P., Nesta, L., \& Schiavo, S. (2010). Financial constraints and firm export behaviour. The World Economy, 33(3), 347-373.

BNDES (2015). Relatório da Administração - sistema BNDES. Retrieved from http://www.bndes.gov.br/SiteBNDES/ export/sites/default/bndes_pt/Galerias/Arquivos/empresa/download/RelatAdm0615.pdf.

Bruck, N. (1998). The role of development banks in the twenty-first century. Journal of Emerging Markets, 3(3), $39-67$.

Bustos, P. (2011). 'Trade Liberalization, Exports, and Technology Upgrading: Evidence on the Impact of MERCOSUR on Argentinian Firms', American Economic Review, 101(1), 304-40.

De Negri, J. A., Borges Lemos, M., \& De Negri, F. (2006). Impact of $R \& D$ incentive program on the performance and technological efforts of Brazilian industrial firms. IDB working paper. Retrieved from https://publications.iadb.org/ handle/11319/2904.

Enflo, K., Henning, M., \& Schön, L. (2014). Swedish regional GDP 1855-2000: Estimations and general trends in the Swedish regional system. In Research in Economic History (pp. 47-89). Bingley: Emerald Publishing.

Galindo, A. J., \& Schiantarelli, F. (Eds.). (2003). Credit constraints and investment in Latin America. Inter-American Development Bank.

Geary, F., \& Stark, T. (2002). Examining Ireland's post-famine economic growth performance. The Economic Journal, 112(482), 919-935.

Gerschenkron, A. (1962). Economic backwardness in historical perspective. Cambridge, MA: Harvard University Press.

Hall, B., \& Maffioli, A. (2008). Evaluating the impact of technology development funds in emerging economies: evidence from Latin America. European Journal of Development Research, 20(2), 172-198.

Izquierdo, A., Micco, A., \& Olivera, M. (Eds.). (2005). IPES 2005: Unlocking Credit: The Quest for Deep and Stable Bank Lending. Inter-American Development Bank.

Lazzarini, S., Musacchio, A., Bandeira-de-Mello, R., \& Marcon, R. (2015). What do state-owned development banks do? Evidence from BNDES, 2002-09. World Development, 66, 237-253.

Levy-Yeyati, E. L., Micco, A., and Panizza, U. (2004). Should the government be in the banking business? The role of state-owned and development banks. IDB working paper. Retrieved from https://papers.ssrn.com/sol3/papers2. cfm?abstract_id=1818717.

López-Acevedo, G., \& Tan, H. W. (2010). Impact evaluation of SME programs in Latin America and Caribbean. World Bank report. Retrieved from http://documents.worldbank.org/curated/en/319161468337915156/ Impact-evaluation-of-SME-programs-in-Latin-America-and-Caribbean.

Mazzucato, M., and Penna, C. (2016). Beyond market failures: The market creating and shaping roles of state investment banks. Journal of Economic Policy Reform, 19(4), 305-326.

Mazzucato, M., \& Penna, C. (2015). The rise of mission-oriented state investment banks: The cases of Germany's KfW and Brazil's BNDES. SPRU working paper. Retrieved from https://www.sussex.ac.uk/webteam/gateway/file. php?name=2015-26-swps-mazzucato-penna.pdf \&site $=25$.

Minetti, R., \& Chun Zhu, S. (2011). Credit constraints and firm export: Microeconomic evidence from Italy. Journal of International Economics, 83(2), 109-125.

Musacchio, A., \& Lazzarini, S. G. (2014). Reinventing state capitalism: Leviathan in business, Brazil and beyond. Cambridge, MA: Harvard University Press.

Najberg, S., Pimentel Puga, F., \& de Souza Oliveira, P. A. (2000). Sobrevivência das firmas no Brasil. Revista do BNDES, 7(13), 33-48.

OECD (2011). OECD economic surveys: Brazil 2011. Paris: OECD Publishing.

Ottaviano, G. I. P., \& Lage de Sousa, F. (2008). The effect of BNDES loans on the productivity of Brazilian manufacturing firms. Retrieved from http://citeseerx.ist.psu.edu/viewdoc/download?doi=10.1.1.587.1080\&rep=rep1\&type=pdf.

Pereira, R. O. (2007). Ação do BNDES sobre o emprego formal: Efeito empresas financiadas. Revista do BNDES, 14(27), 27-42.

Prochnik, M., \& Machado, V. (2008). Fontes de Recursos do BNDES 1995-2007. Revista do BNDES, 14(29), 3-34. 
Rendón, S. (2000). Job creation under liquidity constraints: The Spanish case. Retrieved from http://www.bde.es/f/ webbde/SES/Secciones/Publicaciones/PublicacionesSeriadas/DocumentosTrabajo/01/Fic/dt0101e.pdf .

Rodrik, D. (2004). Industrial policy for the twenty-first century. CEPR discussion paper. Retrieved from https://ideas. repec.org/p/cpr/ceprdp/4767.html.

Segura-Ubiergo, A. (2012). The puzzle of Brazil's high interest rates. IMF working paper. Retrieved from https://www. imf.org/external/pubs/ft/wp/2012/wp1262.pdf.

Schumpeter, J. (1961). The theory of economic development: An inquiry into profits, capital, credit, interest, and the business cycle (revised edition). Cambridge, MA: Harvard University Press.

Stiglitz, J., \& Weiss, A. (1981). Credit rationing in markets with imperfect information. American Economic Review, 71(3), 393-410.

Tasic, I. (2005). Credito às micro e pequenas empresas - assimetria de informação e análise da realidade brasileira. In IPEA (Ed.), Prêmio IPEA 40 anos. Ipea-Caixa 2004: Monografias premiadas (pp. 509-550). Brasilia: Instituto de Pesquisa Econômica Aplicada.

Torres Filho, E. T., \& Pimentel Puga, F. (2006). Empresas apoiadas pelo BNDES geram mais emprego e pagam mais. Visão do Desenvolvimento 17. Retrieved from http://www.bndes.gov.br/SiteBNDES/export/sites/default/bndes_pt/ Galerias/Arquivos/conhecimento/visao/visao_17.pdf.

\section{SUPPORTING INFORMATION}

Additional Supporting Information may be found online in the supporting information tab for this article.

How to cite this article: Maffioli, A., de Negri, J. A., Rodriguez, C. M., Vazquez-Bare, G. Public Credit Programmes and Firm Performance in Brazil. Dev Policy Rev. 2017:35:675702. DOI:10.1111/dpr.12250 